Завод за проучавање културног развитка, Београд

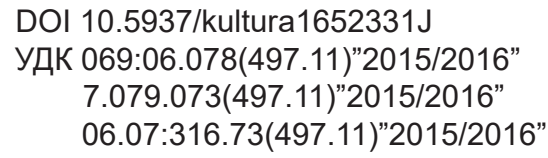

оригиналан научни рад

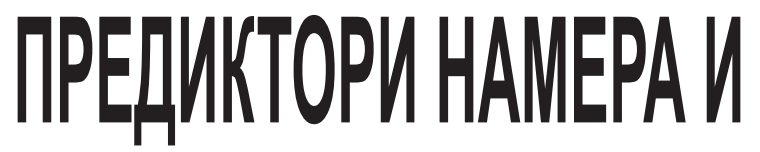
TOHAWALA: MOFY IM MYЗEЕСКИ ФЕСТИВАЛИ ПOВЕНАТИ ПОПУПАРНОСТ NY3EJA?

\begin{abstract}
Сажетак: Музејски фестивали привлаче велики број људи: неки долазе само тада (потенцијални посетиочи редовних музејских програма), док други долазе и мимо фестивала (посетиоци). Ово истраживање спроведено је током фестивала Музеји Србије десет дана од 10 до 10 ( $N$ = 2472). У складу са теоријом планираног понамаға (ТПП) и резултатима ранијег истраживања које је показало да ставови, субјективне норме и опажена контрола јасно диференцирају посетиоце од потенцијалних посетилача редовних музејских програма - први ииь овог истраживања био је да се провери да ли се ти налази реплицирају. Други цииљ је био да се испита да ли ТПП додатно диференщира потениијалне посетиоце у зависности од намера да чешће посећују музеје након фестивала. Резултати су потврдили раније налазе и показали да ставови и опажена контрола додатно диференцирају потенцијалне посетиоие. Дискутоване су теоријске и практичне импликаиије резултата, као и применььвост концепта потенцијалне музејске публике у контексту фестивала.
\end{abstract}

Кључне речи: теорија планираног понашања, публика, посетиоци музеја, културна партищипаџија, став, намера 
Паралелно ${ }^{1}$ са емпиријским налазима о томе да људи, а посебно млади, највећи део слободног времена проводе у различитим врстама забаве, углавном уз ТВ програм и мобилни телефон, аутори упозоравају на могуће негативне ефекте тако структурисаног слободног времена ${ }^{2}$. Наглашава се да је унапређење квалитета активности у слободно време важно за побољшање општег благостања појединца, као и за смањење ризичних облика понашања ${ }^{3}$. При том, иначе слабо заступљени садржаји културе и уметности, углавном се односе на читање књига, одлазак у биоскоп или позориште, док је посећивање музеја међу најмање популарним активностима ${ }^{4}$.

Релативно давно је установљено да демографска обележја нису довољна за предвиђање да ли ће неко посетити музеј или неће, те да је важно идентификовати и психолошке факторе који утичу на доношење одлуке о посети музеју, како би се у складу с тим планирале активности за привлачење нових посетилаца ${ }^{5}$. Пошто је такође утврђено да неки људи једноставно не воле да посећују музеје и воле да раде нешто друго у слободно време, препорука је да се истражи онај део популације који нема навике посећивања музеја, али има позитивне ставове и показује интересовање за њихове програме, па се могу схватити као потенцијални посетиоци (енгл. intenders ${ }^{6}$ ). Како до њих доћи?

У овом раду, основна идеја је била да се концепт потенцијалних посетилаца редовних музејских програма испита у контексту новог музејског фестивала Музеји Србије десет дана од 10 до 10. Наиме, већ је регистрован феномен масовног посећивања музеја у Србији током једне фестивалске

1 Рад је настао у склопу пројекта Завода за проучавање културног развитка Посетиочи манифестачије 'Музеји Србије десет дана од 10 до 10', који финансира Министарство културе Републике Србије.

2 Stepanović, I. (2011). Mladi i zabava: Ima li mesta za zabrinutost? Engrami 33, str. 33-46; Cvetičanin, P. (2007) Kulturne potrebe, navike i ukus građana Srbije i Makedonije, Niš: Odbor za građansku inicijativu.

3 Anić, P. (2014) Hedonic and eudaimonic motives for favourite activities, Primenjena psihologija 7, str. 5-21; Mannell, R. C. and Kleiber, D. A. (1997) A social psychology of leisure, State College, PA: Venture Publishing; Newman, D. B., Tay, L. and Diener, E. (2014) Leisure and subjective wellbeing: A model of psychological mechanisms as mediating factors, Journal of Happiness Studies 15, pp. 555-578.

4 Cvetičanin, Р. нав. дело; Mrđa, S. (2011) Kulturni život i potrebe studenata u Srbiji, Beograd: Zavod za proučavanje kulturnog razvitka.

5 Hood, M. (1983) Staying away: Why people choose not to visit museums, Museum News 61, pp. 150-157; Andersen, A. R. and Belk, R. W. (1980), Predictors of attendance at the performing arts, Journal of Consumer Research 7 , pp. 112-120.

6 Digl, K. (1998) Marketing umetnosti, Beograd: Clio. 
ноћи (Ноћ музеја) насупрот непромењено слабом интересовању за програме истих установа осталим данима ${ }^{7}$. Емпиријски подаци су показали да $39 \%$ испитаника није посетило ниједан музеј током претходних годину дана, али су ипак одлучили то да учине током те једне ноћи, упркос дугачким редовима и обиљу алтернативних понуда, па су означени као потенцијална музејска публика ${ }^{8}$. У поређењу с посетиоцима фестивала који су музеје посећивали у претходном периоду, потенцијални посетиоци су имали негативније ставове о посећивању ових установа.

Специфичност фестивалске атмосфере и програмске понуде Ноћи музеја у поређењу с редовном понудом музеја, те могућа разлика у мотивацији за посећивање једних и других програма (социјални фактори у случају фестивалске публике; едукација, релаксација и друго у случају редовне музејске публике $\left.{ }^{10}\right)$ - указали су на потребу додатне провере применљивости концепта потенцијалних посетилаца редовних музејских програма (у даљем тексту: потенцијални посетиоци) у контексту фестивала. Такође, остало је отворено питање диференцијације потенцијалних посетилаца у погледу намере да посете музеје након фестивала, имајући у виду напомене аутора да категорија потенцијалних посетилаца није јединствена, те да се састоји од група које се могу разликовати у погледу потреба, ставова, намера итд ${ }^{11}$. Управо та питања била су основа за осмишљавање овог истраживања током новог фестивала 2016. године. Концепт новог фестивала подразумева да музеји током десет дана од 10 до 22 часа, уз бесплатан улаз, понуде различите програме (стална поставка, као и трибине, предавања, изложбе итд),

7 Martinović, D. i Jokić, B. (2012) Noć muzeja kao kulturološki i društveni fenomen u Srbiji, Beograd: Zavod za proučavanje kulturnog razvitka.

8 Јокић, Б. и Жежељ, И. (2013) Зашто посећеност 'Ноћи музеја' не предвиђа посећеност музеја током године: однос ставова и понашања, Култура број 140, Београд: Завод за проучавање културног развитка, стр. $445-469$.

9 Crompton, J. L. and McKay, S. L. (1997) Motives of visitors attending festival events, Annals of Tourism Research 2, pp. 425-439.

10 Burton, C., Louviere, J. and Young, L. (2009) Retaining the visitor, enhancing the experience: Identifying attributes of choice in repeat museum visitation, International Journal of Nonprofit and Voluntary Sector Marketing 14, pp. 21-34; Mastandrea, S., Bartoli, G. and Bove, G. (2009) Preferences for ancient and modern art museums: Visitor experiences and personality characteristics, Psychology of Aesthetics, Creativity, and the Arts 3, pp. 164-173; Martinović, D. (2010) Muzejska publika u Srbiji, Beograd: Zavod za proučavanje kulturnog razvitka; Prentice, R., Davies, A. and Beeho, A. (1997) Seeking generic motivations for visiting and not visiting museums and like cultural attractions, Museum Management and Curatorship 16, pp. 45-70.

11 Digl, K. нав. дело. 
ипак непосредније повезане са музејским садржајима него што је то током Ноћи музеја.

Определили смо се за теорију планираног понашања (енгл. Theory of planned behavior ${ }^{12}$ ), као одговарајући теоријски оквир за ово истраживање из више разлога. Најпре, ово је још увек емпиријски најутемељенија теорија о односу ставова и намера, које даље предвиђају понашање у будућности $^{13}$. Њену примену у домену активности у слободно време демонстрирали су и сами аутори теорије ${ }^{14}$. Поред тога, истраживање публике Ноћи музеја такође је спроведено у овом теоријском оквиру, који се показао применљивим за разликовање посетилаца фестивала по навикама посећивања музеја у претходном периоду, као и за предвиђање намера о будућем понашању ${ }^{15}$.

Теорија планираног понашања (ТПП) представља проширену форму теорије разложне акиије (енгл. Theory of reasoned action, TPA ${ }^{16}$ ). Према TРA, понашање је детерминисано намером, а намера ставовима о понашању (вредновање извођења понашања) и субјективним нормама (опажање тога да ли су значајни други наклоњени томе да се испитаник ангажује у понашању које се испитује) - намера заправо може бити детерминисана ставовима или субјективним нормама или и једним и другим. Претпоставка је да други фактори неће имати утицаја на намере и понашање, односно да ће се њихов утицај манифестовати кроз елементе модела. ТПП, поред поменутих фактора, у обзир узима и опажену контролу понашања, односно опажену лакоћу или тешкоћу извођења понашања као предиктора и понашања и намере. ТПП је препоручљива у случајевима када понашање није сасвим под вољном контролом, односно када је његово извођење

12 Ajzen, I. From intentions to actions: A theory of planned behavior, in: Action. control: From cognition to behavior, eds. Kuhi, J. and Beckmann, J. (1985), Heidelberg: Springer, pp. 11-39.

13 Ajzen, I. The theory of planned behaviour: reactions and reflections. Psychology \& Health, 26, pp. 1113-1127; Armitage, C. J. and Conner, M. (2001) Efficacy of the theory of planned behaviour: A meta-analytic review, British Journal of Social Psychology 40, pp. 471-499; Fishbein, M. and Ajzen, I. (2005) The influence of attitudes on behavior, in: The handbook of attitudes, eds. Johnson, B. T. and Zanna, M. P. (2011), Mahwah, NJ: Erlbaum, pp. 173-221.

14 Ajzen, I. and Driver, D. L. (1992) Application of the theory of planned behavior to leisure choice, Journal of Leisure Research 3, pp. 207-224.

15 Јокић, Б. и Жежељ, И. нав. дело.

16 Ajzen, I. and Fishbein, M. (1980) Prediction of goal-directed behavior: Attitudes, intentions, and perceived behavioral control, Journal of Experimental Social Psychology 22, pp. 453-474; Fishbein, M. and Ajzen, I. The influence of attitudes on behavior, in: The handbook of attitudes, eds. Johnson, B. T. and Zanna, M. P. (2005), Mahwah, NJ: Erlbaum pp. 173-221. 
ограничено могућностима, вештинама или способностима. Претпоставка је да намера да се изведе понашање неће бити формирана уколико појединац осећа недостатак контроле над извођењем, чак и уколико су ставови и субјективне норме повољни.

Пошто је било очекивано да ће и током новог фестивала бити присутни и они који иначе немају навику посећивања музеја, ово истраживање је осмишљено са два главна циља, а у складу са елементима које предвиђа ТПП. Први циљ је био да се испита да ли ставови о посећивању музеја, субјективне норме и опажена контрола диференцирају посетиоце музеја (они који то чине и мимо фестивала) од потенцијалних посетилаца (они који не посећују музеје мимо фестивала), те да ли тој диференцијацији доприносе демографске варијабле (пол, старост степен стручне спреме). На тај начин, требало је да се провери да ли се реплицирају резултати из истраживања публике Ноћи музеја, када се показало да су значајни предиктори навика биле све варијабле које предвиђа ТПП, а од демографских варијабли значајан ефекат имао је степен стручне спреме ${ }^{17}$. У том смислу, резултати би могли да укажу на специфичности публике једног и другог фестивала, као и да открију евентуалне правилности у овом домену, које се испољавају у различитим контекстима. Требало би напоменути да неки аутори препознају суштинску разлику између термина публика и посетилац, у том смислу што први термин подразумева критичко размишљање и активан однос према програму, док је могуће да неко посети музеј из тзв. параразлога, нпр. само да би правио некоме друштво ${ }^{18}$. У овом раду, претежно ћемо користити термин музејски посетиоци, али се нећемо строго држати поменуте дистинкције, зато што у овом теоријском контексту она није пресудна, а и стога што је у истраживачком смислу тешко измерити разлике између овако дефинисане музејске публике и оних који јој не припадају, иако јесу посетиоци музејских програма. У дискусији ћемо се још једном осврнути на ове појмове из угла добијених резултата. Такође је важно нагласити да, иако претходно понашање иницијално није било укључено у Ајзенов модел, емпиријски је показано да оно може бити важан предиктор намере или будућег понашања ${ }^{19}$. Претпоставка је да навике могу имати директан

17 Јокић, Б. и Жежељ, И. нав. дело.

18 Dragićević-Šešić, M (1998) Publika, Kultura broj 97, Beograd: Zavod za proučavanje kulturnog razvitka, str. 69-88.

19 Abraham, C. and Sheeran, P. (2003) Implications of goal theories for the theories of reasoned action and planned behavior, Current Psychology 22, pp. 264-280; Smith, J. R., Terry, D. J., Manstead, A. S. R., Louis, W. R., Kotter- 
ефекат на будуће понашање без свесног процеса доношења одлуке, али у новом контексту, претходно понашање заједно са варијаблама које предлаже ТПП може утицати на намеpe, које затим имају ефекта на будуће понашање ${ }^{20}$. У овом истраживању, план је био да се испита однос претходног понашања са ставовима, субјективним нормама и опаженом контролом, што би из перспективе развоја публике могло да буде информативније од податка да они који су раније посећивали музеје имају намеру да и даље то чине. Други циљ је био да се испита да ли ставови, опажена контрола и субјективне норме додатно диференцирају потенцијалне посетиоце у погледу намере да у наредном периоду музеје посећују чешће, што је новина у односу на раније истраживање ${ }^{21}$.

Укратко, планирали смо да ставове, субјективне норме и опажену контролу, с једне стране, повежемо са навикама у претходном периоду (да ли посетиоци музејског фестивала јесу или нису посећивали музеје пре фестивала), а с друге стране са намерама за будућност (да ли намеравају чешће да посећују музеје након фестивала, са посебном занимањем за оне који то нису чинили у претходном периоду).

\section{Memod}

\section{Узорак и прочеедура}

Регионално стратификовани случајни узорак дефинисан је на основу података о посећености музеја на истом фестивалу 2015. године, с тим што су критеријуми за избор испитаника дефинисани тако да буду укључени старији од 14 година, пошто деца основношколског узраста углавном долазе у пратњи родитеља или у оквиру организованих школских посета. Обухваћено је 40.5\% испитаника са територије града Београда, 23.5\% са територије Војводине, 21\% Јужне и Источне Србије и 14.9\% Шумадије и Западне Србије, на укупно 47 музејских локација у 28 градова $(N=2472)$.

Просечна старост испитаника је била 38 година $(S D=15.66)$, а обухваћено је више жена (61.1\%) него мушкараца, што је у складу са уобичајеном структуром посетилаца програма у

man, D. and Wolfs, J. (2008) The attitude-behavior relationship in consumer conduct: The role of norms, past behavior, and self-identity, The Journal of Social Psychology 148, pp. 311-333.

20 Quellette, J. A. and Wood, W. (1998) Habit and intention in everyday life: The multiple processes by which past behavior predicts future behavior, Psychological Bulletin 124, pp. 54-74.

21 Јокић, Б. и Жежељ, И. нав. дело. 
области културе и уметности ${ }^{22}$. У погледу степена стручне спреме, вишу школу или факултет завршило је $42.3 \%$, док је оних са постдипломским образовањем нешто мање (12.2\%). Завршену основну или средњу школу има $45.5 \%$ (од тога $8.9 \%$ основну).

Анкета је реализована од 13. до 21. маја 2016. године. Обучени анкетари бирали су испитанике по стандардизованој процедури случајног избора. Проценат одбијања учешћа у анкетирању је био релативно низак (мање од 5\% на свакој локацији), што је уобичајено у истраживањима у овом домену ${ }^{23}$. Сваком испитанику је понуђено да бира да ли ће сам попунити упитник или ће његове одговоре уписивати анкетар. У $67.7 \%$ случајева, упитник је попунио испитаник, а нису забележена систематска варирања резултата по овој варијабли.

\section{Инструмент}

Креиран је упитник, који је обухватио два сета питања, пошто је истраживање изведено у склопу ширег пројекта о праћењу развоја фестивала. Један сет се односио на евалуацију програма, што није релевантно за ово истраживање. Следи детаљнији опис другог сета питања, односно кључних варијабли и њихових операционализација у складу са циљевима овог истраживања.

Демографске варијабле. Пол, старост (категорије: 15-18, 19-24, 25-34, 35-44, 45-54, 55-64, 65 и више), степен стручне спреме (последња завршена школа: основна, средња, висока / факултет, постдипломске студије).

Претходно понашање (навике посећивања музеја). Питање да ли јесу или нису посетили неки музеј у Србији (ако јесу, колико пута) ограничили смо на период од претходних годину дана, имајући у виду податке о учесталости посећивања музеја и уобичајено разликовање посетилаца (оних који то чине ретко, повремено или често) од оних који немају навику посећивања одређених програма културе и уметности ${ }^{24}$.

22 Јокић, Б. и Мрђа, С. (2014) Посетиоци јесењих београдских манифестаuија и фестивала, Београд: Завод за проучавање културног развитка; Martinović, D. (2010) Muzejska publika u Srbiji, Beograd: Zavod za proučavanje kulturnog razvitka; Mrđa, S. (2016), Demokratske vrednosti i kulturna participacija u Srbiji (nepublikovana doktorska disertacija), Fakultet političkih nauka, Univerzitet u Beogradu, Beograd.

23 Јокић, Б. и Мрђа, С. нав. дело.

24 Јокић, Б. и Жежељ, И. нав. дело; 2013; Mrđa, S. (2011) Kulturni život i potrebe studenata u Srbiji, Beograd: Zavod za proučavanje kulturnog razvitka. 
Намера за будуће понашағе. Ова варијабла операционализована је с обзиром на социјалну пожељност одговора (у ранијем истраживању, више од 70\% испитаника у свим категоријама по претходном понашању одговорило је да ће музеје посећивати сигурно или вероватно чешће $\mathrm{e}^{25}$ ). Покушали смо да умањимо овај ефекат тако што смо намеру да се музеји чешће посећују након фестивала мерили петостепеном скалом са половима сигурно чешће и сигурно ређе, али је средња опција била подједнако често као до сада уместо нисам сигурна/а. То значи да није могуће директно поређење намера посетилаца и потенцијалних посетилаца, али то за ово истраживање заправо није релевантно, пошто је било очекивано да ће они који су посетили неки музеј током претходних годину дана у било којој формулацији питања и понуђених одговора исказати намеру да то учине и у наредних годину дана (у овом случају, очекивано је да ће одабрати опције подједнако често или чешће него до сада). Пошто су нас првенствено занимале намере потенцијалних посетилаца, избор средње опције у њиховом случају значио би да немају намеру да посете музеј ни у наредних годину дана.

Опажена контрола. Операционализована је директним питањем С обзиром на Ваше могућности, колико је за Вас лако / тешко да посетите неки од локалних музеја? у складу са уобичајеним решењима у ТПП. Испитаници су процењивали на седмостепеној скали с половима лако изводљиво и тешко изводљиво.

Субјективне норме. У складу са моделом ТПП, операционализоване су као опажени ставови значајних других о томе колико је важно да испитаник посећује музеје - оцена на петостепеној скали с половима мисле да је веома важно да ја посећујем музеје и мисле да је потпуно неважно да ја посећујем музеје и средњом опцијом не мисле о томе / не знам шта мисле.

Став о понашағу. Став о посећивању музеја операционализовали смо у складу са ТПП, а да бисмо умањили социјалну пожељност, понуђене одговоре формулисали смо тако да се непосредно искуство у музеју контрастира са посредним искуством путем електронских медија, тако да су на питање Колико је по Вашем мишьењу посећивање музеја битно? понуђени одговори били: 1. прилично је битно, нема замене за сазнања и доживљаје у музеју; 2. битно је, али може да се замени информацијама из медија (ТВ, интернет, радио); 3. није много битно, све то може да се сазна и доживи путем медија; 4. садржаји које нуде музеји прилично су небитни.

25 Јокић, Б. и Жежељ, И. нав. дело. 


\section{Резултати}

\section{Предиктори навика посећивања музеја}

Ниједан музеј у Србији током последњих годину дана није посетило $41.6 \%$ испитаника (потенцијални посетиоци). Међу посетиоцима, највише је оних који су то учинили 1-3 пута $(32.7 \%$ од укупног узорка, $N=809)$, док је најмање оних који су посетили неки музеј 10 или више пута $(7.4 \%, N=$ 184).

Демографске варијабле. Бинарна логистичка регресија $(N=2408)$ с критеријумском варијаблом навике посећивања музеја током претходних годину дана (категорије: посетили / нису посетили) и демографским варијаблама (пол, степен стручне спреме, старост) као предикторима, показала је да је модел статистички значајан, али да објашњава свега $7.9 \%$ варијансе $\left(\chi^{2}(28)=145.56, p<.001\right.$, Negelkerke $R^{2}=$ .079). Главни ефекти пола и старости нису били статистички значајни, док је ефекат степена стручне спреме био маргинално значајан, али је била статистички значајна интеракција степена стручне спреме и старости $($ Wald $(11)=23.33$, $p<.05)$. Додатне анализе показале су да је степен стручне спреме значајан предиктор навика посећивања музеја у категоријама старијих од 24 године (већа је шанса да су музеј посетили они који су завршили вишу школу / факултет или постдипломске студије него они са завршеном основном / средњом школом), док у млађим старосним категоријама степен стручне спреме није значајан предиктор (по последњој завршеној школи, млађи су заправо разврстани у једну или две категорије).

Став о понашағу, субјективне норме и опажена контрола. Опажена контрола, субјективне норме и став према понашању одређени су као предиктори у првом кораку хијерархијске бинарне логистичке регресије (категорије: посетили / нису посетили), а интеракција старости и степена стручне спреме укључена је као предиктор у другом кораку. Резултати су показали да модел у првом кораку објашњава $15.3 \%$ варијансе $\left(\chi^{2}(5)=289.58, p<.001\right.$, Negelkerke $\left.R^{2}=.153\right)$, а у другом кораку нешто више, $19 \%$ варијансе $\left(\chi^{2}(16)=363.63\right.$, $p<.001$, Negelkerke $\left.R^{2}=.190\right)$. Иако је у оба случаја реч о релативно малом проценту варијансе, што оставља могућност деловања других фактора, главни ефекти свих варијабли из модела ТПП били су статистички значајни (Табела 1). Већа је шанса да су музеј посетили они који имају позитивније субјективне норме, као и они који имају позитивнију оцену опажене контроле односно лакоће организовања посете. Ставови о понашању такође су повезани са претходним 


\section{БИЉАНА ЈОКИЋ}

понашањем на очекивани начин: веће су шансе да су музеј посетили они који сматрају да су непосредни доживљаји у музеју незаменљиви, него они који сматрају да та искуства могу да се замене садржајима из медија или да посете уопште нису битне.

Табела 1 Резултат бинарне логистичке регресије за критеријумску варијаблу навике посећивања музеја

\begin{tabular}{lcccccc}
\hline & $B$ & S.E. & Wald & $d f$ & Sig. & $\operatorname{Exp}(B)$ \\
\hline ссс * старост & & & 69.32 & 12 & .000 & \\
Став 0 понашању & & & 59.77 & 3 & .000 & \\
Став 0 понашању (1) & 0.76 & 0.11 & 50.61 & 1 & .000 & 2.13 \\
Став 0 понашању (2) & 0.79 & 0.26 & 9.46 & 1 & .002 & 2.20 \\
Став 0 понашању (3) & 1.64 & 0.66 & 6.09 & 1 & .014 & 5.13 \\
Субјективне норме & -0.30 & 0.05 & 30.17 & 1 & .000 & 0.74 \\
Опажена контрола & -0.27 & 0.03 & 86.51 & 1 & .000 & 0.76 \\
\hline
\end{tabular}

Напомена: За варијаблу став о понашању, референтна категорија је прва опција (нема замене за искуства у музеју). У циљу прегледности, нису приказани редови који се односе на ефекте укрштених категорија степена стручне спреме (ccc) и старости.

Однос елемената ТПП и навика посећивања музеја доследно се испољава и када се у обзир узме учесталост посећивања музеја. Категорије испитаника по броју остварених посета (ниједна, 1-3, 4-9, 10 и више посета), статистички значајно се разликују по субјективним нормама, ( $F$ (2394, $\left.3)=38.13, p<.001, \eta_{\mathrm{p}}{ }^{2}=.046\right)$, као и по опаженој контроли, $\left(F(2389,3)=60.67, p<.001, \eta_{\mathrm{p}}^{2}=.046\right.$ (Табела 2). У оба случаја, post hoc Tuckey test показао је да се потенцијални посетиоци значајно разликују од свих осталих, али и да се они који су најчешће посећивали музеје (10 и више посета) такође значајно разликују од свих.

Табела 2 Субјективне норме и опажена контрола према учесталости посећивања музеја током претходних годину дана;

\begin{tabular}{lllll}
\hline \multirow{2}{*}{ Број посета } & \multicolumn{2}{l}{ Субјективне норме } & \multicolumn{2}{l}{ Опажена контрола } \\
\cline { 2 - 5 } \cline { 2 - 5 } Ниједна & 3.25 & SE & M & SE \\
$1-3$ & 3.49 & 0.02 & 5.79 & 0.06 \\
$4-9$ & 3.53 & 0.05 & 5.95 & 0.05 \\
10 и више & 3.91 & 0.07 & 6.44 & 0.07 \\
\hline
\end{tabular}

Напомена: У табели су приказане аритметичке средине (M) и њихове стандардне грешке (SE). Субјективне норме оцењиване су на петостепеној скали, а опажена контрола на седмостепеној скали. 


\section{БИЉАНА ЈОКИЋ}

Када се став о понашағу додатно анализира према учесталости посећивања музеја, такође се бележе статистички значајне разлике: $\chi^{2}(2390,9)=168.68, p<.001$. Очекивано, у свим категоријама, већина испитаника оценила је да посећивање музеја јесте битно, али са порастом броја посета, растао је и проценат оних који сматрају да нема замене за сазнања и доживљаје у музејима, док се истовремено смањивао проценат оних који сматрају да посећивање музеја јесте битно, али може да се замени информацијама из медија (Табела 3).

Табела 3 Ставови о посећивању музеја, према учесталости посећивана музеја током претходних годину дана

\begin{tabular}{|c|c|c|c|c|}
\hline \multirow{2}{*}{ Ставови о посећивању музеја } & \multicolumn{4}{|c|}{ Број посета музејима током претходних годину дана } \\
\hline & ниједна & 1 до 3 & 4 до 9 & 10 и више \\
\hline $\begin{array}{l}\text { Битно је, нема замене за } \\
\text { сазнања и доживљаје у музеју }\end{array}$ & $60.1 \%$ & $76.4 \%$ & $86.5 \%$ & $92.9 \%$ \\
\hline $\begin{array}{l}\text { Битно је, али може дасе замени } \\
\text { информацијама из медија (ТВ, } \\
\text { интернет, радио) }\end{array}$ & $32.2 \%$ & $20.8 \%$ & $12.2 \%$ & $6.0 \%$ \\
\hline $\begin{array}{l}\text { Није много битно, све то може } \\
\text { да се сазна и доживи путем } \\
\text { медија }\end{array}$ & $5.9 \%$ & $2.4 \%$ & $1.3 \%$ & $1.1 \%$ \\
\hline Прилично је небитно & $\begin{array}{l}1.8 \% \\
100.0 \%\end{array}$ & $\begin{array}{l}0.4 \% \\
100.0 \%\end{array}$ & $\begin{array}{l}0.0 \% \\
100.0 \%\end{array}$ & $\begin{array}{l}0.0 \% \\
100.0 \%\end{array}$ \\
\hline
\end{tabular}

Намера да се музеји у Србији посећују чешће након манифестаичје

У категоријама посетилаца, на питање о намерама да чешће посећују музеје након фестивала, проценат одговора подједнако често као до сада расте са порастом броја претходних посета, док се смањује заступљеност одговора да ће се музеји посећивати чешће него до сада (Табела 4). Ако се резултати интерпретирају из перспективе предвиђања понашања у наредних годину дана, то би значило да готово $100 \%$ у свим категоријама посетилаца има намеру да посети бар један музеј у наредних годину. Међутим, 36.3\% оних који нису остварили ниједну посету музеју током последњих годину дана, нема намеру да промени понашање у наредном периоду, а још 3.4\% намерава да посећује музеје ређе него до сада. У складу с другим циљем овог истраживања, у наставку смо анализирали предикторе њихових намера.

Предиктори намера потенцијалних посетилача. За потребе наредних анализа варијаблу намера рекодирали смо тако да поредимо испитанике који имају мање или више изражену намеру да посећују музеје чешће него до сада (сигурно 


\section{БИЉАНА ЈОКИЋ}

чешће и вероватно чешће, $N=622$ ) са онима који немају намеру то да чине (категорије подједнако, вероватно ређе, сигурно ређе, $N=398)$.

Табела 4 Намера да се музеји посећују чешће након фестивала, према учесталости посећивања музеја током претходних годину дана

\begin{tabular}{lllll}
\hline \multirow{2}{*}{ Понућени одговори } & \multicolumn{4}{c}{ Број посета музејима током претходних годину дана } \\
\cline { 2 - 5 } & ниједна & 1 до 3 & 4 до 9 & 10 и више \\
\hline Сигурно чешће него до сада & $26.4 \%$ & $27.8 \%$ & $28.4 \%$ & $25.5 \%$ \\
Вероватно чешће него до сада & $34.0 \%$ & $33.3 \%$ & $23.5 \%$ & $15.8 \%$ \\
Подједнако често као до сада & $36.3 \%$ & $37.8 \%$ & $47.6 \%$ & $58.7 \%$ \\
Вероватно ређе него до сада & $2.5 \%$ & $0.9 \%$ & $0.5 \%$ & $0.0 \%$ \\
Сигурно ређе него до сада & $0.9 \%$ & $0.2 \%$ & $0.0 \%$ & $0.0 \%$ \\
& $100.0 \%$ & $100.0 \%$ & $100.0 \%$ & $100.0 \%$ \\
\hline
\end{tabular}

Ефекти демографских обележја нису били статистички значајни, па смо у бинарну логистичку регресију укључили намеру као критеријумску варијаблу (категорије: има / нема), а предиктори су биле варијабле које предлаже ТПП: став о понашању, субјективне норме и опажена контрола. Модел, који је обухватио 1008 испитаника, у целини је био статистички значајан $\left(\chi^{2}(5)=86.96, p<.001\right)$, објашњавао је $11.2 \%$ варијансе и правилно је предвиђао $65.7 \%$ случајева. Статистички значајни су били главни ефекти става о понашању и опажене контроле: веће су шансе да позитивну намеру имају они који имају позитивнију оцену опажене контроле, као и они који непосредно искуство у музејима сматрају незаменљивим, него они који сматрају да медији могу да замене искуства из музеја или да су посете музејима у мањој или већој мери небитне (Табела 5).

Табела 5 Резултати бинарне логистичке регресије за критеријумску варијаблу намера да се музеји чешће посећују након манифестације у оквиру потенцијалних посетилаца;

\begin{tabular}{lcccccc}
\hline & $B$ & S.E. & Wald & $d f$ & Sig. & $\operatorname{Exp}(B)$ \\
\hline Став 0 понашању & & & 37.89 & 3 & .000 & \\
Став 0 понашању (1) & -0.73 & 0.15 & 25.26 & 1 & .000 & 0.48 \\
Став 0 понашању (2) & -1.19 & 0.30 & 15.72 & 1 & .000 & 0.31 \\
Став 0 понашању (3) & -1.57 & 0.59 & 7.01 & 1 & .008 & 0.21 \\
Субјективне норме & 0.12 & 0.09 & 1.84 & 1 & .175 & 1.12 \\
Опажена контрола & 0.19 & 0.04 & 23.57 & 1 & .000 & 1.21 \\
\hline
\end{tabular}

Напомена: За варијаблу став о понашању, референтна категорија је прва опција (нема замене за искуства у музеју). 
БИЉАНА ЈОКИЋ

\section{Дискусија}

Аутори истичу значај квалитета активности у слободно време и за појединца и за друштво у целини, док се истовремено откривају упозоравајући трендови, у којима се између осталог издваја релативно слаба заступљеност садржаја културе и уметности, а међу најмање популарним активностима су посете музејима ${ }^{26}$. Како повећати популарност и посећеност музеја? У овом истраживању проверили смо применљивост концепта потенцијалне музејске публике у контексту музејског фестивала, водећи се варијаблама које предлаже теорија планираног понашања ${ }^{27}$. На тај начин, с једне стране, резултати истраживања доприносе проверама ТПП у овом домену, а с друге стране, могу имати и практичну примену у развоју музејске публике.

На новом фестивалу, Музеји Србије десет дана од 10 до 10, у приближно истом проценту били су заступљени они који нису посетили ниједан музеј у Србији током последњих годину дана (41.6\%), као што је било у случају Ноћи музеја $(39 \%)^{28}$. По плану, анализирано је да ли се они (потенцијални посетиоци редовних музејских програма) разликују од оних који јесу посетили неки музеј током претходних годину дана (посетиоци). Најпре, издвојићемо два налаза, која су у складу са резултатима претходних истраживања о културној партиципацији и може се рећи да се доследно и очекивано потврђују ${ }^{29}: 1$. од демографских варијабли статистички значајан предиктор понашања у претходном периоду је степен стручне спреме (након 24 године старости, пошто ова варијабла готово уопште не диференцира млађе испитанике који су још увек у систему школовања); 2. они који јесу посетили неки музеј током претходних годину дана имају

26 Anić, P. (2014) Hedonic and eudaimonic motives for favourite activities, Primenjena psihologija 7, pp. 5-21; Mrđa, S. нав. дело; Stepanović, I. (2011) Mladi i zabava: Ima li mesta za zabrinutost? Engrami 33, str. 33-46.; Cvetičanin, Р. нав. дело.

27 Ajzen, I. From intentions to actions: A theory of planned behavior, in: Action. control: From cognition to behavior, eds. Kuhi, J. and Beckmann, J. (1985), Heidelberg: Springer, pp. 11-39.

28 Јокић, Б. и Жежељ, И. (2013) Зашто посећеност 'Ноћи музеја' не предвиђа посећеност музеја током године: однос ставова и понашања, Култура број 140, Београд: Завод за проучавање културног развитка, стр. 445-469.

29 Abraham, C. and Sheeran, P. (2003) Implications of goal theories for the theories of reasoned action and planned behavior, Current Psychology 22, pp. 264-280; Brida, J. G., Disegna, M. and Scuderi, R. (2014) The behaviour of repeat visitors to museums: Review and empirical findings, Quality \& Quantity 48, pp. 2817-2840; Јокић, Б. и Жежељ, И. нав. дело; Мрђа, С. нав. дело; Qullette, J. A. and Wood, W. нав. дело; Smith, нав. дело. 
намеру то да учине (подједнако често или чешће) и у наредних годину дана. Међутим, сазнање о томе да је већа шанса да образованији посете музеје него мање образовани, као ни податак да ће они који су раније посећивали музеје наставити то да чине и у наредном периоду, није од велике помоћи за привлачење нових посетилаца ${ }^{30}$. У том смислу, кориснији би могли да буду резултати који указују на разлике између посетилаца и потенцијалних посетилаца у погледу ставова, субјективних норми и опажене контроле: иако ове варијабле објашњавају релативно мали проценат варијансе и у случају навика и у случају намера за посећивање музеја у будућности, главни ефекти варијабли које обухвата модел ТПП били су статистички значајни. Иначе, када је реч о културној партиципацији, подразумева се сложени утицај разноврсних фактора, од којих су неки и екстерни, као нпр. приступачност културних садржаја, културна понуда итд ${ }^{31}$.

Као у истраживању публике Ноћи музеја, резултати овог истраживања показали су да посетиоци у поређењу с потенцијалним посетиоцима редовних музејских програма: 1. позитивније процењују непосредно искуство у музеју у поређењу са информацијама из медија (ставови о понашању), 2. позитивније оцењују ставове значајних других (субјективне норме) и 3 . позитивније оцењују лакоћу организовања посете музеју (опажена контрола). Ове варијабле не само да диференцирају категорију посетилаца од потенцијалних посетилаца, него и доследно диференцирају категорије посетилаца по учесталости посећивања музеја: они који најчешће посећују музеје (бар десет пута годишње), а који се могу сматрати редовним посетиоцима, издвајају се по најпозитивнијим ставовима и субјективним нормама, те најповољније оцењеном опаженом контролом. Ако се потенцијална музејска публика схвати као део популације који још увек нема развијене навике посећивања музеја, али може да их развије, пошто има позитивне ставове и интересовања ${ }^{32}$, одређење потенцијалне публике могло би се односити не само на категорију оних који нису посећивали музеје мимо фестивала, него и на неке категорије посетилаца. Наиме, највећи проценат посетилаца у музеј долази свега 1-3 пута годишње. При том, сваки трећи испитаник у категорији потенцијалних посетилаца и сваки пети у категорији оних

30 Подразумева се да је налаз о улози степена стручне спреме у овом домену значајан утолико што упућује на потребу успостављања континуиране системске сарадње ресора културе и образовања, што излази из оквира овог рада.

31 Cvetičanin, Р. нав. дело.

32 Digl, K. (1998) Marketing umetnosti, Beograd: Clio. 
који најређе посећују музеје - сматра да посете музејима јесу битне, али да ипак могу да се замене информацијама из медија. Другим речима, концепт потенцијалне музејске публике може се проширити и на посетиоце музеја који то чине ретко или повремено, иако су у поређењу с онима који ниједном нису посетили музеј пре фестивала, испољили позитивније ставове, субјективне норме и опажену контролу.

Резултати у вези са другим циљем овог истраживања - о додатној диференцијацији посетилаца музејског фестивала који нису посетили ниједан музеј у претходном периоду показали су да су став о понашању и опажена контрола значајни предиктори намере да се музеји чешће посећују након фестивала, док субјективне норме то нису. У истраживањима реализованим у ТПП парадигми, субјективне норме су се иначе показале слабим предиктором намера, у поређењу са ставовима и опаженом контролом ${ }^{33}$. Према ТРА, на намеру може утицати било став, било субјективна норма или и једно и друго, а ТПП додаје опажену контролу као неопходан услов ${ }^{34}$. Стога, можемо закључити да резултати овог истраживања подржавају претпоставке ТПП. Подразумева се да би за прецизнију потврду ТПП било потребно осмислити начин за евидентирање будућег понашања, како би се проверило да ли је намера његов значајан предиктор. Пошто je то уобичајени методолошки проблем у истраживањима у ТПП парадигми, решења најчешће представљају ретроактивни извештаји испитаника: након дефинисаног периода пошто је регистрована намера, испитаници извештавају да ли јесу или нису извели одређено понашање у претходном периоду $^{35}$. У овом истраживању, задржали смо се на испитивању односа претходног понашања и варијабли из модела ТПП. Када се то повеже са утврђеним предикторима намере оних који немају развијене навике, открива се специфичан статус субјективних норми: оне су значајан предиктор навика, али не и намера о посећивању музеја у будућности ако тог понашања није било у претходном периоду. У наредним истраживањима било би занимљиво осмислити начин да се прецизније испита улога субјективних норми у развијању навика посећивања музеја: да ли оне у неком наредном тренутку додатно утичу на намеру пре извођења прве посете музеју или имају ефекат на понављање посета (преко намере или директним утицајем на понашање).

33 Armitage, C. J. and Conner, M. (2001) Efficacy of the theory of planned behaviour: A meta-analytic review, British Journal of Social Psychology 40, pp. 471-499.

34 Ajzen, I. and Fishbein, М. нав. дело; Ajzen, I. нав. дело.

35 Armitage, C. J. and Conner, М. нав. дело. 


\section{БИЉАНА ЈОКИЋ}

Такође, могао би детаљније да се истражи проблем опажене контроле, будући да се она показала као значајан предиктор и навика и намера о посећивању музеја у будућности. Овај концепт у оквиру ТПП углавном је испитан у вези са понашањима која су у мањој мери под вољном контролом (нпр. дијета, престанак пушења итд $\left.{ }^{36}\right)$. У контексту организовања посете музеју, опажена контрола може бити повезана са различитим опаженим препрекама, па треба осмислити начин да се оне прецизније сагледају, будући да испитаници нису увек у стању да их експлицитно наведу ${ }^{37}$.

У дугорочном смислу, континуирано истраживање опажених препрека, ставова о музејима, те начина да се ти ставови формирају или мењају, било би значајно и у теоријском и у практичном смислу: акумулирала би се научна сазнања о овим феноменима у специфичном контексту уметности и културе, што би истовремено могло да допринесе трансформацији музеја, тако да постану препознатљива места за провођење креативно осмишљеног слободног времена. 


\section{БИЉАНА ЈОКИЋ}

\section{ЛИТЕРАТУРА:}

Abraham, C. and Sheeran, P. (2003) Implications of goal theories for the theories of reasoned action and planned behavior, Current Psychology 22, p. 264-280.

Ajzen, I. From intentions to actions: A theory of planned behavior, in: Action.control: From cognition to behavior, eds. Kuhi, J. and Beckmann, J. (1985), Heidelberg: Springer, pp. 11-39.

Ajzen, I. (2011) The theory of planned behaviour: reactions and reflections, Psychology \& Health, 26, p. 1113-1127.

Ajzen, I. and Driver, D. L. (1992) Application of the theory of planned behavior to leisure choice, Journal of Leisure Research 3, p. 207-224.

Ajzen, I. \& Fishbein, M. (1980) Prediction of goal-directed behavior: Attitudes, intentions, and perceived behavioral control, Journal of Experimenlal Social Psychology 22, p. 453-474.

Andersen, A. R. and Belk, R. W. (1980) Predictors of attendance at the performing arts, Journal of Consumer Research 7, p. 112-120.

Anić, P. (2014) Hedonic and eudaimonic motives for favourite activities, Primenjena psihologija 7, str. 5-21.

Armitage, C. J. and Conner, M. (2001) Efficacy of the theory of planned behaviour: A meta-analytic review, British Journal of Social Psychology 40, p. 471-499.

Brida, J. G., Disegna, M. and Scuderi, R. (2014) The behaviour of repeat visitors to museums: Review and empirical findings Quality \& Quantity 48, p. 2817-2840.

Burton, C., Louviere, J. and Young, L. (2009) Retaining the visitor, enhancing the experience: Identifying attributes of choice in repeat museum visitation, International Journal of Nonprofit and Voluntary Sector Marketing 14, p. 21-34.

Crompton, J. L. and McKay, S. L. (1997) Motives of visitors attending festival events, Annals of Tourism Research 2, p. 425-439.

Cvetičanin, P. (2007) Kulturne potrebe, navike i ukus građana Srbije $i$ Makedonije, Niš: Odbor za građansku inicijativu.

Digl, K. (1998) Marketing umetnosti, Beograd: Clio.

Dragićević-Šešić, M. (1998) Publika, Kultura broj 97, Beograd: Zavod za proučavanje kulturnog razvitka, str. 69-88.

Fishbein, M. and Ajzen, I. (1975) Belief, Attittide, Intention and Behavior: An Introduction to Theory and Research, Reading, MA:

Addison-Wesley.

Fishbein, M. and Ajzen, I. The influence of attitudes on behavior, in: The handbook of attitudes, eds. Johnson, B. T. and Zanna, M. P. (2005), Mahwah, NJ: Erlbaum, pp. 173-221.

Hein, H. S. (2000) The museum in transition: A philosophicai perspective, Washington: Smithsonian Institution Press. 


\section{БИЉАНА ЈОКИЋ}

Hood, M. (1983) Staying away: Why people choose not to visit museums, Museum News 61, p. 150-157.

Јокић, Б. и Мрђа, С. (2014) Посетиочи јесењих београдских манифестација и фестивала, Београд: Завод за проучавање културног развитка.

Јокић, Б. и Жежељ, И. (2013) Зашто посећеност `Ноћи музеја' не предвића посећеност музеја током године: однос ставова и понашања, Култура број 140, Београд: Завод за проучавање културног развитка, стр. 445-469.

Kolber, F. (2010) Marketing u kulturi i umetnosti, Beograd: Clio.

Mannell, R. C. and Kleiber, D. A. (1997) A social psychology of leisure, State College, PA: Venture Publishing.

Martinović, D. (2010) Muzejska publika u Srbiji, Beograd: Zavod za proučavanje kulturnog razvitka.

Martinović, D. i Jokić, B. (2012) Noć muzeja kao kulturološki $i$ društveni fenomen u Srbiji, Beograd: Zavod za proučavanje kulturnog razvitka.

Mastandrea, S., Bartoli, G. and Bove, G. (2009) Preferences for ancient and modern art museums: Visitor experiences and personality characteristics, Psychology of Aesthetics, Creativity, and the Arts 3, p. 164-173.

Mrđa, S. (2011) Kulturni život i potrebe studenata u Srbiji, Beograd: Zavod za proučavanje kulturnog razvitka.

Мрђа, С. (2016) Демократске вредности и културна партиципаицја у Србији (непубликована докторска дисертација), Факултет политичких наука, Универзитет у Београду, Београд.

Newman, D. B., Tay, L. and Diener, E. (2014) Leisure and subjective well-being: A model of psychological mechanisms as mediating factors, Journal of Happiness Studies 15, p. 555-578.

Quellette, J. A. and Wood, W. (1998) Habit and intention in everyday life: The multiple processes by which past behavior predicts future behavior, Psychological Bulletin 124, p. 54-74.

Prentice, R., Davies, A. and Beeho, A. (1997) Seeking generic motivations for visiting and not visiting museums and like cultural attractions, Museum Management and Curatorship 16, p. 45-70.

Smith, J. R., Terry, D. J., Manstead, A. S. R., Louis, W. R., Kotterman, D. and Wolfs, J. (2008) The attitude-behavior relationship in consumer conduct: The role of norms, past behavior, and self-identity, The Journal of Social Psychology 148, p. 311-333.

Stepanović, I. (2011) Mladi i zabava: Ima li mesta za zabrinutost? Engrami 33, str. 33-46. 
БИЉАНА ЈОКИЋ

Biljana Jokić
Center for Study in Cultural Development, Belgrade

\title{
PREDICTORS OF INTENTIONS AND BEHAVIOR: CAN MUSEUMS' FESTIVALS INCREASE THE POPULARITY OF MUSEUMS?
}

\begin{abstract}
Research results reveal that visiting a museum is one of the least popular leisure activities. However, museums attract many visitors during festivals: there are people who visit museums exclusively during festivals (potential visitors of museums' regular programs), and those who come to museums both before and during festivals (visitors). This research was conducted during the festival Museums of Serbia ten days from 10am to $10 \mathrm{pm}(\mathrm{N}=2472)$. Following the theory of planned behavior (TPB) and previous results on the research of the audience of the Museum Night festival, when it was found that the visitors compared to potential visitors have more positive subjective norms, perceived control, and attitudes toward visiting museums - the first goal of this study was to examine whether those results replicate in the context of new museum festival. The second goal was to examine the possibility of further differentiation of potential visitors: whether attitudes, subjective norms and perceived control predict their intentions to visit museums after the festival. Results showed that visitors had more positive attitudes, subjective norms, and perceived control than potential visitors, while regular museum visitors (who visited museums at least ten times during the previous year) had the most positive ones. Additionally, attitudes and perceived control differentiate subcategories of potential visitors with and without intention to visit museums after the festival. The results are discussed within the framework of TPB. In particular, the role that TBP variables have in explaining past behavior has been considered, with respect to identified predictors of the intentions to visit museums after the festival. Applicability of TBP model for the purpose of museum audience development has been discussed, as well as further implications on the concept of potential museum audience in a festival context.
\end{abstract}

Key words: theory of planned behavior, audience, museum visitors, cultural participation, intention, attitude 